\title{
Optimization of adefovir therapy in chronic hepatitis $B$ according to baseline predictors and on-treatment HBV DNA: a 5-Year prospective study
}

Hui Lu ${ }^{1,2}$, Da Ying Geng ${ }^{1}$, Fei Shen ${ }^{1}$, Jing Yao Zhang ${ }^{1}$, Bing Lu ${ }^{3}$ and Li Xian Ma ${ }^{2^{*}}$

\begin{abstract}
Background: Adefovir Dipivoxil (ADV) is an important agent to suppress hepatitis B virus (HBV) replication with suboptimal effect on virological and serological response. To optimize Adefovir therapy in chronic hepatitis B (CHB) patients with hepatitis B e antigen ( $\mathrm{HBeAg}$ ) positive, we studied the baseline parameters and on-treatment HBV DNA for favorable outcomes.
\end{abstract}

Methods: 48 patients were enrolled in the study and followed up for 5 years prospectively. Baseline characteristics, virological, serological and biochemical parameters as well as on treatment HBV DNA were assessed in prediction of favorable outcomes.

Results: 1. The patients with baseline alanine aminotransferase (ALT) $\geq 5 \times$ the upper limit of normal (ULN, 40 IU/L) had higher rates of viral response (VR), HBeAg loss and HBeAg seroconversion at year 5 compared to the patients with ALT < $5 \times$ ULN (VR: 75\% vs 43.8\%, $p=0.035$; HBeAg loss: 43.9\% vs 13.8\%, $\mathrm{p}=0.017$; HBeAg seroconversion: $37.9 \%$ vs $13.8 \%, p=0.035)$; Patients with baseline HBV DNA $<10^{9}$ copies $/ \mathrm{ml}$ and ALT $\geq 3 \times$ ULN had more chance of HBeAg seroconversion (40.9\% vs $8.7 \%, \mathrm{p}=0.012$ ), while in patients with $\mathrm{HBeAg}<800 \mathrm{~s} / \mathrm{co}$ or $\mathrm{HBsAg}<5000 \mathrm{IU} /$ $\mathrm{ml}$ higher rates of HBeAg loss were achieved. 2. HBV DNA level $<10^{4}$ copies $/ \mathrm{ml}$ at week 24 was predictive for VR (96.0\% vs 40.9\%, $\mathrm{P}<0.001)$, HBeAg loss $(84.0 \%$ vs $36.3 \%, P=0.001)$ and $\mathrm{HBeAg}$ seroconversion $(36.0 \%$ vs $9.1 \%, \mathrm{P}=$ 0.030).

Conclusions: ADV treatment should be started for patients with baseline ALT $\geq 5 \times$ ULN or patients with ALT $\geq 3 \times$ ULN and HBV DNA $<10^{9}$ copies/ml. Lower level of $\mathrm{HBeAg}(<800 \mathrm{~s} / \mathrm{co})$ and $\mathrm{HBsAg}(<5000 \mathrm{IU} / \mathrm{ml})$ may be regarded as referenced factors. In patients with serum HBV DNA $<10^{4}$ copies $/ \mathrm{ml}$ at week 24 the therapy should continue, and a favorable outcome may be achieved in 5 years or longer.

Keywords: hepatitis B, chronic, Adefovir Dipivoxil, therapy, hepatitis B virus, hepatitis Be antigen positive, predictor

\section{Background}

Adefovir Dipivoxil (ADV) is a nucleotide analogue for treatment of hepatitis B. Long term treatment with ADV is well tolerated and may produce long-term virological, biochemical, serological and histological improvement [1]. Compared with lamivudine (LAM) and telbivudine, ADV correlated resistance develops less

\footnotetext{
*Correspondence: Ixmdoctor@126.com

${ }^{2}$ Department of Infectious Diseases, Qilu Hospital of Shandong University, Jinan, China

Full list of author information is available at the end of the article
}

frequently but ADV has less potent activity against hepatitis $B$ virus (HBV). It has been reported that the rates of HBV DNA negative, hepatitis $B$ e antigen (HBeAg) loss and $\mathrm{HBeAg}$ seroconversion were 39\%, 58\% and $48 \%$ respectively in the subjects with $\mathrm{HBeAg}$ positive chronic hepatitis B (CHB) treated with ADV $10 \mathrm{mg}$ once daily for 5 years, and $66 \%$ of them achieved alanine aminotransferase (ALT) normalization and 20\% developped HBV mutant [2]. These data highlighted an urgent need to identify the predictors that will help to find candidates who may likely benefit from ADV or,
C Biomed Central

() 2011 Lu et al; licensee BioMed Central Ltd. This is an Open Access article distributed under the terms of the Creative Commons Attribution License (http://creativecommons.org/licenses/by/2.0), which permits unrestricted use, distribution, and reproduction in any medium, provided the original work is properly cited. 
alternatively, determine whether other extensive treatment is needed. Recently, It has been reported that baseline and on-treatment serum HBV DNA were significant predictors for sustained viral response in $\mathrm{CHB}$ patients with pegylated interferon(Peg-IFN) and nucleos (t)ide analogues(NAs) treatment [3-8]. In the GLOBE study of $\mathrm{HBeAg}$-positive patients treated with telbivudine, HBV DNA negative at week 24 was more predictive for responses than other parameters [9]. Similar results were reported in LAM and ADV therapies $[10,11]$. However, the association of these predictors with effect of long term ADV treatment has rarely been reported.

The aim of this study is to assess baseline and ontreatment serum markers in prediction of long term response in the early phase of treatment with ADV among $\mathrm{HBeAg}$-positive $\mathrm{CHB}$ patients so as to identify the most beneficial patients from ADV treatment and optimize the therapy.

\section{Methods}

\section{Subject population}

$48 \mathrm{HBeAg}$-positive CHB patients who enrolled in the study were treated with ADV (provided by GlaxoSmithKline) and followed up for 5 years. All patients were seropositive for hepatitis B surface antigen (HBsAg) and HBeAg for more than 6 months and with baseline ALT $\geq 1.2 \times$ the upper limit of normal (ULN, $40 \mathrm{IU} / \mathrm{L}$ ) and HBV DNA $\geq 10^{6}$ copies/ $\mathrm{ml}$ before treatment. Criteria for exclusion included serum creatinine greater than $1.5 \mathrm{mg} / \mathrm{dl}(130 \mu \mathrm{mol} / \mathrm{L})$; seropositivity for hepatitis $C$ or $D$ virus or human immunodeficiency virus. No patients received LAM or any other anti-HBV therapy within 6 months prior to treatment. Other treatments were not used during the therapy. Written informed consent was obtained from all patients and the study was approved by the Ethical Committee of Jinan Infectious Disease Hospital.

\section{Study Design}

All patients were followed up at weeks 4, 12, 24, 52 and every 12-16 weeks after week 52 for detection of serum biochemical parameters, serum viral load (Roche COBAS Amplicore HBV Monitor PCR assay, lower limit of detection 300 copies/ml) and HBV markers (micro particle enzyme immunoassay with ABBOTT reagents). DNA sequencing and phylogenetic analysis of HBV genome were evaluated at baseline. Serum samples at first time point from subjects who experienced a breakthrough of HBV DNA (HBV DNA level increased by $1 \log _{10}$ copies/ml or more than the treatment nadir) were assessed for the development of ADV-associated mutations (rtA181V and rtN236T) in the HBV polymerase.

\section{Efficacy End Points}

The primary efficacy endpoints in this study were HBeAg seroconversion defined as combination of $\mathrm{HBeAg}$ loss and development of hepatitis B e antibody accompanied by HBV DNA negative $(<300$ copies/ml). The secondary efficacy endpoints are $\mathrm{HBeAg}$ loss and viral response (VR) defined as HBV DNA negative.

\section{Statistical Analyses}

Descriptive statistics such as the mean, median, and standard deviation for each continuous variable and frequencies for each categorical variable were used to summarize the data as well as detect outliers and missing values. The associations of baseline and on-treatment parameters with virological, serological and biochemical responses were assessed using Chi-square tests or Fisher's exact tests. All p values were calculated with twosided significance level of 0.05. Data analyses were performed using SAS 9.2 (SAS Institute, Inc, Cary, North Carolina).

\section{Results}

1. Baseline characteristics of demographic, clinical and laboratory data

Except for 1 woman who withdrew because of pregnance at week 104, 47 patients completed 5 years' follow up. All patients were ethnically Chinese and HBV genotype $\mathrm{C}$ positive. The baseline demographic, clinical and virological data are shown in Table 1.

\section{Virological, serological and biochemical response} Of 47 patients, the rates of VR, accumulative $\mathrm{HBeAg}$ loss, $\mathrm{HBeAg}$ seroconversion and ALT normalization in the end of the fifth year were $66.0 \%, 36.2 \%, 23.4 \%$ and $70.2 \%$, respectively. The rates of HBeAg loss increased over time, and the proportion of patients with ALT normalization and HBV DNA < 300 copies/ml achieved maximal values after 2 and 4 years respectively (Figure 1 ). Virus breakthrough was found in 4 patients but ADV correlated variants were detectable only in 3 of them.

Table 1 Baseline characteristics of demographic, clinical and laboratory data

\begin{tabular}{ll}
\hline variables & \\
\hline Age in years, mean \pm SD & $31.7 \pm 6.6$ \\
Male, \% & $85.1 \%$ \\
HBV genotype C, \% & $100 \%$ \\
Baseline ALT, IU/L & $216.3 \pm 169.7$ \\
Baseline HBV DNA $\left(\log _{10}\right.$ Copies $\left./ \mathrm{ml}\right)$ & $8.5 \pm 0.8$ \\
Baseline HBeAg $\left(\log _{10}\right)$ & $2.8 \pm 0.4$ \\
BaselineHBsAg $\left(\log _{10}\right)$ & $3.7 \pm 0.5$ \\
\hline
\end{tabular}




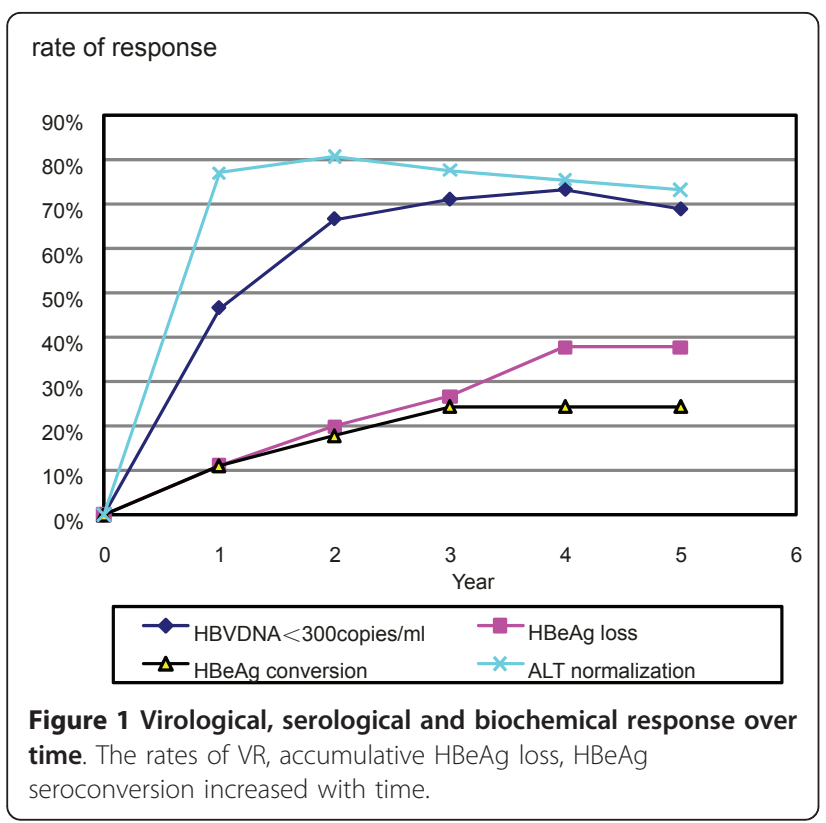

\section{Relationship between baseline parameters and 5-year response}

We evaluated baseline characteristics such as ALT, HBV DNA, HBsAg and HBeAg level in prediction of 5-year response and found baseline ALT was a potential predictor of outcome. Patients with baseline ALT $\geq 5 \times$ ULN were more likely to have HBeAg seroconversion, HBeAg loss and VR than patients with ALT $<5 \times$ ULN (Table 2), while in patients with $\mathrm{HBeAg}<800 \mathrm{~s} / \mathrm{co}$ or $\mathrm{HBsAg}<5000 \mathrm{IU} / \mathrm{ml}$ higher rates of HBeAg loss were achieved. The baseline HBeAg level predicted VR too, as 88.9\% patients with baseline $\mathrm{HBeAg}<800$ s/co became HBV DNA negative, whereas baseline HBV DNA level alone was not a significant predictor for HBeAg seroconversion, HBeAg loss or VR.

Even so, there was a trend that the rate of VR in the 5 years decreased with the higher levels of baseline viral load (Figure 2). In subgroup analyses, we found in patients with baseline HBV DNA $<10^{9}$ copies $/ \mathrm{ml}$, ALT was positively associated with VR and HBeAg seroconversion. The rate of $\mathrm{HBeAg}$ seroconversion was

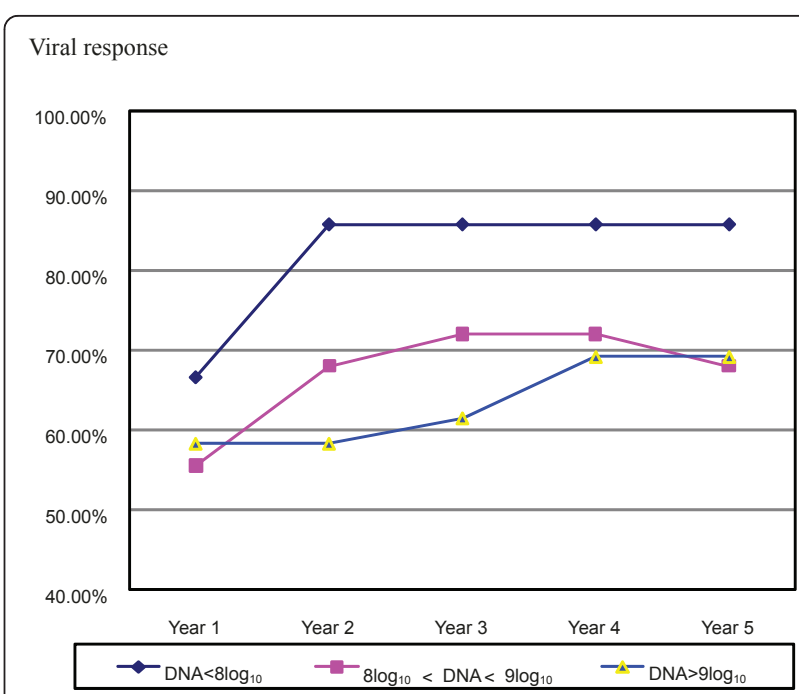

Figure 2 Viral response in patients with different levels of baseline viral load. The rate of VR in the 5 years decreased with the higher levels of baseline viral load although no statistical significance was observed.

significantly higher in patients with ALT $\geq 3 \times$ ULN when compared to the patients with ALT $<3 \times \mathrm{ULN}$ ( $40.9 \%$ vs $8.7 \%, \mathrm{p}=0.012$ ).

\section{Impact of on-treatment HBV DNA on outcomes}

The relationships between on-treatment HBV DNA levels and 5-year outcomes were presented in Table 3. Patients with serum HBV DNA level $<4 \log _{10}$ copies/ml at week 24 had higher rates of $\mathrm{HBeAg}$ seroconversion, HBeAg loss and VR compared to the patients with serum HBV DNA $\geq 4 \log _{10}$ copies $/ \mathrm{ml}$. The drop of the serum HBV DNA $\geq 3$ $\log _{10}$ copies $/ \mathrm{ml}$ at week 4 and HBV DNA undetectable at week 52 can predict VR and HBeAg loss while the drop of the serum HBV DNA $\geq 4 \log _{10}$ copies/ml at week 12 was significantly associated with the increased rates of $\mathrm{HBeAg}$ loss and HBeAg seroconversion.

\section{Resistance to ADV}

Four patients experienced viral breakthrough at week 104, 184, 208, 260 respectively. HBV DNA rebounded to

Table 2 Baseline predictors and 5-year outcomes

\begin{tabular}{|c|c|c|c|c|c|c|}
\hline & VR $\%$ & P-value & HBeAg loss \% & P-value & $\mathrm{HBeAg}$ seroconversion $\%$ & P-value \\
\hline$A L T \geq 5 \times U L N$ & $75.0 \%$ & 0.035 & $43.9 \%$ & 0.017 & $37.9 \%$ & 0.035 \\
\hline $\mathrm{ALT}<5 \times \mathrm{ULN}$ & $43.8 \%$ & & $13.8 \%$ & & $13.8 \%$ & \\
\hline $\mathrm{HBeAg}<800 \mathrm{~s} / \mathrm{co}$ & $88.9 \%$ & 0.027 & $77.8 \%$ & 0.045 & $27.8 \%$ & 0.831 \\
\hline $\mathrm{HBeAg} \geq 800 \mathrm{~s} / \mathrm{co}$ & $47.6 \%$ & & $38.0 \%$ & & $19.0 \%$ & \\
\hline $\mathrm{HBsAg}<5000 \mathrm{IU} / \mathrm{ml}$ & $80.0 \%$ & 0.132 & $80.0 \%$ & 0.026 & $27.8 \%$ & 0.200 \\
\hline $\mathrm{HBsAg} \geq 5000 \mathrm{IU} / \mathrm{ml}$ & $59.3 \%$ & & $48.1 \%$ & & $24.1 \%$ & \\
\hline HBV DNA $<9 \log _{10}$ copies $/ \mathrm{ml}$ & $71.9 \%$ & 0.494 & $61.8 \%$ & 0.621 & $26.5 \%$ & 0.702 \\
\hline HBV DNA $\geq 9 \log _{10}$ copies $/ \mathrm{ml}$ & $69.2 \%$ & & $53.9 \%$ & & $15.4 \%$ & \\
\hline
\end{tabular}


Table 3 Impact of on-treatment HBV DNA on 5-year outcomes

\begin{tabular}{|c|c|c|c|c|c|c|c|}
\hline & $\mathrm{N}$ & VR & P-value & HBeAg loss & P-value & HBeAg seroconversion & P-value \\
\hline drop of HBV DNA $\geq 3 \log _{10}$ copies $/ \mathrm{ml}$ at week 4 & 12 & $91.7 \%$ & 0.06 & $91.7 \%$ & 0.013 & $41.7 \%$ & 0.083 \\
\hline drop of HBV DNA $<3 \log _{10}$ copies $/ \mathrm{ml}$ at week 4 & 35 & $62.6 \%$ & & $51.4 \%$ & & $17.1 \%$ & \\
\hline drop of HBV DNA $\geq 4 \log _{10}$ copies/ml at week 12 & 20 & $85.0 \%$ & 0.366 & $80.0 \%$ & 0.028 & $45.0 \%$ & 0.006 \\
\hline drop of HBV DNA $<4 \log _{10}$ copies $/ \mathrm{ml}$ at week 12 & 27 & $60.0 \%$ & & $48.0 \%$ & & $7.4 \%$ & \\
\hline DNA level $<4 \log _{10}$ copies $/ \mathrm{ml}$ at week 24 & 25 & $96.0 \%$ & $<0.001$ & $84.0 \%$ & 0.001 & $36.0 \%$ & 0.030 \\
\hline DNA level $\geq 4 \log _{10}$ copies $/ \mathrm{ml}$ at week 24 & 22 & $40.9 \%$ & & $36.3 \%$ & & $9.1 \%$ & \\
\hline DNA negative at week 52 & 27 & $100 \%$ & $<0.001$ & $88.9 \%$ & $<0.001$ & $33.3 \%$ & 0.062 \\
\hline DNA positive at week 52 & 20 & $45.0 \%$ & & $20.0 \%$ & & $10.0 \%$ & \\
\hline
\end{tabular}

$2.2 \times 10^{4}-6.5 \times 10^{7}$ copies $/ \mathrm{ml}$, and ALT flares were found in 3 patients but none of them developped liver decompensation. ADV correlated mutations were detected in 3 of the 4 patients ( 1 of them with N236T and another 2 with combination of A181T/V and N236T mutations in HBV DNA polymerase). None of the patients who achieved HBV DNA $<4 \log$ copies $/ \mathrm{ml}$ at week 24 experienced viral breakthrough. All four patients were then given additional LAM for combination therapy.

\section{Safety analysis}

Four patients had an increase in serum creatinine of more than the peak value of normal $(1.5 \mathrm{mg} / \mathrm{dl})$, but the abnormality was not confirmed by a consecutive sample test. Three patients had slightly elevated serum uric acid in incontinuous samples. No action was taken regarding study medication dosing.

\section{Discussion}

The response of ADV monotherapy for $\mathrm{HBeAg}$ positive $\mathrm{CHB}$ patients is less satisfying comparing with that of other oral NAs, but in many Asian countries like China, tenofovir is unavailable, ADV is still the only nucleotide analogue without cross resistance to other NAs to date [12-14]. The optimization of ADV therapy according to patients' baseline and on-treatment parameters may be a feasible strategy to increase the response. It was ever reported that ADV might provide additional benefits for $\mathrm{HBeAg}$ seroconversion in patients with pre-treatment HBV DNA levels between $10^{7}$ and $10^{8}$ copies $/ \mathrm{ml}$ [15]. Subgroup analysis of GLOBE Study with telbivudine revealed that patients with $\mathrm{ALT} \geq 2 \times \mathrm{ULN}$ and $\mathrm{HBV}$ DNA $<10^{9}$ copies $/ \mathrm{ml}$ had more chance of VR, HBeAg seroconversion and ALT nomalization at year 2 [16]. There were also similar reports about long term LAM therapy [10]. In our study baseline factors such as ALT predicted long term response to ADV therapy. Patients with higher baseline ALT $(\geq 5 \times$ ULN) had more chance of optimal outcomes, and lower levels of $\mathrm{HBeAg}(<800$ s/co) and $\mathrm{HBsAg}(<5000 \mathrm{IU} / \mathrm{ml})$ also predicted $\mathrm{HBeAg}$ loss. In addition, there was a trend that patients with lower HBV DNA level might have higher rates of VR, $\mathrm{HBeAg}$ loss and $\mathrm{HBeAg}$ seroconversion although no statistical significance was observed in our study. Our findings may be limited by the relatively small sample size. When we combined baseline ALT and HBV DNA, we found that patients with baseline HBV DNA $<10^{9}$ copies/ml and ALT $\geq 3 \times$ ULN had more favorable outcomes. An elevated ALT level indicates increased clearance to HBV infected hepatocytes. It was reported that Chinese patients with ALT $>5 \times$ ULN had high rate of spontaneous $\mathrm{HBeAg}$ seroconversion even without treatment [17], but treatment with anti-virus medicaments can improve the chance of HBeAg seroconversion and decrease the disease progression which has been proved in many clinical studies [2,18-20]. Similarly, HBeAg level may reflect the clearance capability of a HBV infected body to HBV infected hepatocytes [21,22]. The significance of HBsAg in treatment of patients with $\mathrm{CHB}$ is being paid close attention to recently. HBsAg may reflect the level of cccDNA in liver and the decrease during treatment with pegylated interferon alfa-2a may predict the sustained viral response $[23,24]$. More studies are needed to elucidate HBsAg variations during treament with NAs. In our study patients with lower level of baseline HBeAg and HBsAg had more chance of HBeAg loss which indicaties that baseline HBeAg and HBsAg may be regarded as subsidiary parameters in pretreatment evaluation.

Early HBV DNA reduction may also contribute to VR and HBeAg seroconversion in some studies $[11,15,25]$. It's generally accepted that therapy can be optimized by monitoring of serum HBV DNA levels during treatment with oral NAs and week 24 is the most important time point recommended to assess efficacy in LAM and telbivudine therapy [26], but whether it's reasonable in treatment of suboptimal antiviral drug like ADV remains controversial. We selected week 4, 12, 24 and 52 as time points in our study and found that serum HBV DNA < $4 \log _{10}$ copies/ml at week 24 was predictive for VR, $\mathrm{HBeAg}$ loss and $\mathrm{HBeAg}$ seroconversion after 5-year treatment, The drop of HBV DNA from baseline $\geq 3$ $\log _{10}$ copies/ml at week $4, \geq 4 \log _{10}$ copies/ml at week 
12 and HBV DNA turning negative at week 52 can also predict favorable outcomes although not as optimal as HBV DNA $<4 \log _{10}$ copies/ml at week 24 . None of the patients who achieved HBV DNA $<4 \log _{10}$ copies/ml at week 24 experienced viral breakthrough. Accordingly we recommend serum HBV DNA level $<4 \log _{10}$ copies $/ \mathrm{ml}$ at week 24 as one of the major predictors for long term outcomes in patients with ADV therapy.

Our study has some limitations because of its small sample size and lack of a control group. However, in our study most patients completed 5 years' follow-up, and the detection method was advanced. The findings may give some evidence to manage $\mathrm{HBeAg}$ positive patients who intend to accept or have already accepted ADV therapy.

\section{Conclusions}

ADV treatment may be initiated to patients with baseline ALT $\geq 5 \times \mathrm{ULN}$ or patients with ALT $\geq 3 \times \mathrm{ULN}$ and HBV DNA $<10^{9}$ copies $/ \mathrm{ml}$, lower level of $\mathrm{HBeAg}(<800$ $\mathrm{s} / \mathrm{co})$ or HBsAg $(<5000 \mathrm{IU} / \mathrm{ml})$ may be regarded as referenced factors. Patients will be followed up regularly and long term outcome may be predicted according to on-treatment HBV DNA. For patients with HBV DNA level $<10^{4}$ copies $/ \mathrm{ml}$ at week 24 therapy should continue and favorable outcomes may be achieved in 5 years or longer. For others with HBV DNA $\geq 10^{4}$ copies/ $\mathrm{ml}$ at week 24 , some modifications for the therapeutic regimen such as addition or switch to another agent should be considered to enhance the long term response.

\section{List of abbreviations}

ADV: Adefovir Dipivoxil; ALT: alanine aminotransferase; CHB: chronic hepatitis B; HBeAg: hepatitis B e antigen; HBV: hepatitis B virus; LAM: lamivudine; NAs: nucleos(t)ide analogues; ULN: upper limit of normal; VR: viral response.

\section{Acknowledgements}

This study was supported by grants from the National Natural Science Foundation of China (NSFC No.81071340) and Natural Science Foundation of Shandong Province (No. Y2008C68).

\section{Author details \\ ${ }^{1}$ Jinan Infectious Disease Hospital, affiliated to Shandong University, Jinan, China. ${ }^{2}$ Department of Infectious Diseases, Qilu Hospital of Shandong University, Jinan, China. ${ }^{3}$ Brigham \& Women's Hospital, Harvard Medical School, Boston, MA, USA.}

\section{Authors' contributions}

$\mathrm{HL}$ conceived of the study, participated the design, carried out the study and drafted the manuscript. DYG carried out laboratory work, FS and JYZ participated in following up of patients and data collecting. BL participated in the design of the study and performed the statistical analysis. LXM participated in the design and coordination and helped to draft the manuscript. All authors read and approved the final manuscript.

\section{Competing interests}

The authors declare that they have no competing interests.
Received: 7 June 2011 Accepted: 21 September 2011

Published: 21 September 2011

\section{References}

1. Marcellin $P$, Chang $T$, Lim SG, Tong MJ, Sievert W, Shiffman ML, Jeffers L, Goodman Z, Wulfsohn MS, Xiong S, Fry J, Brosgart CL: Adefovir dipivoxil for the treatment of hepatitis $B$ e antigen-positive chronic hepatitis $B$. N Engl J Med 2003, 348:808-816.

2. Marcellin P, Chang TT, Lim S, Sievert W, Tong M, Arterburn S, BorrotoEsoda K, Frederick D, Rousseau F: Long-term efficacy and safety of adefovir dipivoxil for the treatment of hepatitis $B$ e antigen-positive chronic hepatitis B. Hepatology 2008, 48:750-758.

3. Fried MW, Piratvisuth T, Lau GK, Marcellin P, Chow WC, Cooksley G, Luo KX, Paik SW, Liaw YF, Button P, Popescu M: HBeAg and hepatitis B virus DNA as outcome predictors during therapy with peginterferon alfa-2a for HBeAg-positive chronic hepatitis B. Hepatology 2008, 47(2):428-434.

4. Chien RN, Liaw YF, Atkins M: Pretherapy alanine transaminase level as a determinant for hepatitis $B$ e antigen seroconversion during lamivudine therapy in patients with chronic hepatitis B. Asian Hepatitis Lamivudine Trial Group. Hepatology 1999, 30(3):770-774.

5. Liaw YF: On-treatment outcome prediction and adjustment during chronic hepatitis B therapy: now and future. Antivir Ther 2009, 14:13-22.

6. Bonino F, Marcellin P, Lau GK, Hadziyannis S, Jin R, Piratvisuth T, Germanidis G, Yurdaydin C, Diago M, Gurel S, Lai MY, Brunetto MR, Farci P, Popescu M, McCloud P: Predicting response to peginterferon alpha-2a, lamivudine and the two Combined for $\mathrm{HBeAg}$-negative chronic hepatitis B. Gut 2007, 56:699-705.

7. Lau GK, Piratvisuth T, Luo KX, Marcellin P, Thongsawat S, Cooksley G, Gane E, Fried MW, Chow WC, Paik SW, Chang WY, Berg T, Flisiak R, McCloud P, Pluck N, Peginterferon Alfa-2a HBeAg-Positive Chronic Hepatitis B Study Group: Peginterferon Alfa-2a, lamivudine, and the combination for HBeAg-positive chronic hepatitis B. Engl J Med 2005, 352(26):2682-2695.

8. Gish RG, Lau DT, Schmid P, Perrillo R: A pilot study of extended duration of peginterferon alfa-2a for patients with hepatitis $B$ e antigen-negative chronic hepatitis B. Am J Gastroenterol 2007, 102:2718-2723.

9. Zeuzem S, Gane E, Liaw YF, Lim SG, DiBisceglie A, Buti M, Chutaputti A, Rasenack J, Hou J, O'Brien C, Nguyen TT, Jia J, Poynard T, Belanger B, Bao W, Naoumov NV: Baseline characteristics and early on-treatment response predict the outcomes of 2 years of telbivudine treatment of chronic hepatitis B. J Hepatol 2009, 51(1):11-20.

10. Yuen MF, Fung J, Seto WK, Wong DK, Yuen JC, Lai CL: Combination of baseline parameters and on-treatment hepatitis $B$ virus DNA levels to start and continue patients with lamivudine therapy. Antivir Ther 14:679-685.

11. Llop E, De la Revilla J, Pons F, Peñas B, Martínez JL, Abreu L, Calleja JL: Decrease in viral load at weeks 12 and 24 in patients with chronic hepatitis $B$ treated with lamivudine or adefovir predicts virological response at week 48. Rev Asp Enferm Dig 2009, 101(11):763-767.

12. Lok AS, McMahon BJ: Chronic hepatitis B: update 2009. Hepatology 2009 50(3):661-662.

13. Lok AS, Zoulim F, Locarnini S, Bartholomeusz A, Ghany MG, Pawlotsky JM, Liaw YF, Mizokami M, Kuiken C: Antiviral drug-resistant HBV: standardization of nomenclature and assays and recommendations for management. Hepatology 2007, 46:254-265.

14. Qi X, Xiong S, Yang H, Miller M, Delaney WE: Invitro susceptibility of adefovir-associated hepatitis B virus polymerase mutations to other antiviral agents. Antivir Ther 2007, 12:355-362.

15. Reijnders JG, Leemans WF, Hansen BE, Pas SD, de Man RA, Schutten M, Janssen HL: On-treatment monitoring of adefovir therapy in chronic hepatitis B: virologic response can be assessed at 24 weeks. J Viral Hepat 2009, 16:113-120.

16. Zeuzem S, Buti M, Gane EJ: Baseline parameters predict both early virologic response and longer term outcomes for telbivudine-treated patients with chronic hepatitis B. The GLOBE study. Hepatology 2007, 46(Suppl 1):681 A

17. Yuen M-F, Yuan H-J, Hui C-K, Wong D-K, Wong WM, Chan AO, Wong BC, Lai $C L$ : A large population study of spontaneous $\mathrm{HBeAg}$ seroconversion and acute exacerbation of chronic hepatitis B infection: implications for antiviral therapy. Gut 2003, 52(3):416-419. 
18. Poynard T, Ngo Y, Marcellin P, Hadziyannis S, Ratziu V, Benhamou Y, Adefovir Dipivoxil 437 and 438 Study Groups: Impact of adefovir dipivoxil on liver fibrosis and activity assessed with biochemical markers (FibroTest-ActiTest) in patients infected by hepatitis B virus. J Viral Hepat 2009, 16(3):203-213.

19. Liaw YF, Sung JJ, Chow WC, Farrell G, Lee CZ, Yuen H, Tanwandee T, Tao QM, Shue K, Keene ON, Dixon JS, Gray DF, Sabbat J, Cirrhosis Asian Lamivudine Multicentre Study Group: Lamivudine for patients with chronic hepatitis B and advanced liver disease. N Engl J Med 2004, 351(15):1521-1531.

20. Liaw YF, Leung N, Guan R, Lau GK, Merican I, McCaughan G, Gane E, Kao JH, Omata M, Asian-Pacific consensus update working party on chronic hepatitis B: Asian-Pacific consensus statement on the management of chronic hepatitis B: a 2005 update. Liver Int 2005, 25(3):472-489.

21. Brunetto MR, Oliveri F, Rocca G, Criscuolo D, Chiaberge E, Capalbo M, David E, Verme G, Bonino F: Natural course and response to interferon of chronic hepatitis B accompanied by antibody to hepatitis B e antigen. Hepatology 1989, 10(2):198-202

22. Chu CM, Hung SJ, Lin J, Tai DI, Liaw YF: Natural history of hepatitis B e antigen to antibody seroconversion in patients with normal serum aminotransferase levels. Am J Med 2004, 116(12):829-834.

23. Thompson AJ, Nguyen T, Iser D, Ayres A, Jackson K, Littlejohn M, Slavin J, Bowden S, Gane EJ, Abbott W, Lau GK, Lewin SR, Visvanathan K, Desmond PV, Locarnini SA: Serum hepatitis B surface antigen and hepatitis $B$ e antigen titers: disease phase influences correlation with viral load and intrahepatic hepatitis B virus markers. Hepatology 2010, 51(6):1933-1944.

24. Brunetto MR, Moriconi F, Bonino F, Lau GK, Farci P, Yurdaydin C, Piratvisuth T, Luo K, Wang Y, Hadziyannis S, Wolf E, McCloud P, Batrla R, Marcellin P: Hepatitis $B$ virus surface antigen levels: a guide to sustained response to peginterferon alfa-2a in HBeAg-negative chronic hepatitis $B$. Hepatology 2009, 49(4):1141-1150.

25. Tseng KC, Cheng PN, Wu IC, Chang CK, Chou AL, Liu WC, Chang TT: HBV DNA level as an important determinant of e antigen seroconversion of chronic hepatitis B during adefovir dipivoxil therapy. Hepatogastroenterology 2009, 56(91-92):813-818.

26. Keeffe EB, Dieterich DT, Han SH, Jacobson IM, Martin P, Schiff ER, Tobias H: A treatment algorithm for the management of chronic hepatitis $B$ virus infection in the United States: 2008 update. Clin Gastroenterol Hepatol 2008, 6(12):1315-1341, quiz 1286.

doi:10.1186/1743-422X-8-444

Cite this article as: Lu et al:: Optimization of adefovir therapy in chronic hepatitis B according to baseline predictors and on-treatment HBV DNA: a 5-Year prospective study. Virology Journal 2011 8:444.

\section{Submit your next manuscript to BioMed Central and take full advantage of:}

- Convenient online submission

- Thorough peer review

- No space constraints or color figure charges

- Immediate publication on acceptance

- Inclusion in PubMed, CAS, Scopus and Google Scholar

- Research which is freely available for redistribution

Submit your manuscript at www.biomedcentral.com/submit
CioMed Central 